Article

\title{
Preparation of Hierarchically Structured Polystyrene Surfaces with Superhydrophobic Properties by Plasma-Assisted Fluorination
}

\author{
Martin Minařík ${ }^{1,2}$, Erik Wrzecionko ${ }^{1,2}$, Antonín Minařík ${ }^{1,2}$, Ondřej Grulich ${ }^{1,2}$,

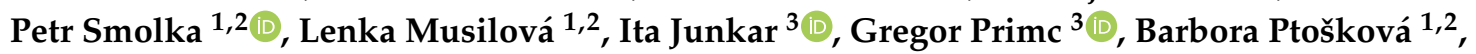 \\ Miran Mozetič ${ }^{3}$ and Aleš Mráček ${ }^{1,2, *}$ \\ 1 Department of Physics and Materials Engineering, Faculty of Technology, Tomas Bata University in Zlín, \\ Vavrečkova 275, 76001 Zlín, Czech Republic; mminarik@utb.cz (M.M.); wrzecionko@utb.cz (E.W.); \\ minarik@utb.cz (A.M.); ondrej.grulich85@gmail.com (O.G.); smolka@utb.cz (P.S.); lmusilova@utb.cz (L.M.); \\ b_ptoskova@utb.cz (B.P.) \\ 2 Centre of Polymer Systems, Tomas Bata University in Zlín, Třída Tomáše Bati 5678, \\ 76001 Zlín, Czech Republic \\ 3 Jožef Stefan Institute, Jamova cesta 39, 1000 Ljubljana, Slovenia; ita.junkar@ijs.si (I.J.); \\ gregor.primc@ijs.si (G.P.); miran.mozetic@guest.arnes.si (M.M.) \\ * Correspondence: mracek@utb.cz; Tel.: +420-733-690-668
}

Received: 17 February 2019; Accepted: 16 March 2019; Published: 20 March 2019

\begin{abstract}
The nanotexturing of microstructured polystyrene surfaces through $\mathrm{CF}_{4}$ plasma chemical fluorination is presented in this study. It is demonstrated that the parameters of a surface micropore-generation process, together with the setup of subsequent plasma-chemical modifications, allows for the creation of a long-term (weeks) surface-stable micro- and nanotexture with high hydrophobicity (water contact angle $>150^{\circ}$ ). Surface micropores were generated initially via the time-sequenced dosing of mixed solvents onto a polystyrene surface (Petri dish) in a spin-coater. In the second step, tetrafluoromethane $\left(\mathrm{CF}_{4}\right)$ plasma fluorination was used for the generation of a specific surface nanotexture and the modulation of the surface chemical composition. Experimental results of microscopic, goniometric, and spectroscopic measurements have shown that a single combination of phase separation methods and plasma processes enables the facile preparation of a wide spectrum of hierarchically structured surfaces differing in their wetting properties and application potentials.
\end{abstract}

Keywords: surface pores; polystyrene; nanotexture; plasma; superhydrophobic

\section{Introduction}

Hierarchically structured surfaces with well-defined textures play very significant roles in sophisticated applications in sensors [1], photonics [2], tissue engineering [3], and superhydrophobic materials [4-12]. Generally, these surfaces are prepared in several steps combining mechanical, laser machining, physicochemical, and plasma technologies [13-16]. The so-called "breath figures" is one of the very popular and promising approaches [17-19]. In principle, the polymer surface is swollen by a "good" volatile solvent. This process is aimed at a defined humidity and temperature. The temperature of the swollen polymer layer decreases with the solvent evaporation, and the water vapor condensates on it. These water drops can ideally create hexagonal organized structures called "breath figures". The droplets do not coalesce because of the Marangoni convections [20] in the droplets or the precipitation of polymers onto the water droplet interfaces [21]. The "breath figures" method has many variations and technological modifications, and some of them can lead to the formation of 
very impressive honeycomb-like structures, not only in the thin surface layer, but porous structures in bulk can also be created $[4,13,21,22]$.

Recently, other methods based on similar principles of mixed (good and pure solvents) solutions have been published [23]. This approach is based on the time-sequenced dispensing of a mixture of good and poor solvents on the rotating polystyrene surface. The phase separation-a process that occurs during application to the surface of the substrate-may be caused by temperature change, poor solvents [24,25], chemical reactions [26], or shear deformation [27]. The same process, published in recent work [23], was used in this paper for the preparation of the microstructured porous surfaces.

The excellent hydrophobic properties of a surface are not achieved solely by chemical compositions. The hierarchical geometric structure of the surface is necessary for the achievement of a water contact angle above $160^{\circ}$ [28-30]. We can find many theoretical models (e.g., Wenzel or Cassie-Baxter models) describing the influence of the structure and the chemical composition of the surface on wetting [31-39]. Surface functionalization by the incorporation of non-polar groups is very often used for improving hydrophobicity. There are numerous techniques for the chemical modification of surface properties, but one of them is predominant nowadays. Plasma surface modifications are very effective tools for chemical treatment, etching, thin film deposition, and nanofabrication [40-50]. Inductively coupled plasma with $\mathrm{CF}_{4}$ or $\mathrm{C}_{4} \mathrm{~F}_{8}$ as process gases can be used to render polystyrene surfaces superhydrophobic [51,52]. The man-made superhydrophobic surfaces, however, are subject to aging, and with time, they lose their water-repellent properties [52]. These undesirable processes can be caused by the reorganization of chemical groups from the surface to the bulk and also by the water vapor (humidity) [53,54].

This paper is related to our recent research dealing with the creation of microstructured porous surfaces of polystyrene [23]. Those surfaces were originally prepared for bio-applications, with a water contact angle below $115^{\circ}$. In this work, $\mathrm{CF}_{4}$ plasma was used for nanostructure generation on a polystyrene microstructured surface that was recently prepared. As can be seen, hierarchically structured polystyrene with non-polar chemical groups on the surface $\left(\mathrm{CF}\right.$ and $\left.\mathrm{CF}_{2}\right)$ exhibited superhydrophobic properties (water contact angle over $155^{\circ}$ ), and these properties were stable over several weeks.

\section{Materials and Methods}

\subsection{Materials}

Polystyrene (PS) Petri dishes with a diameter of $3.4 \mathrm{~cm}$, radiation-sterilized, free from pyrogens, and with DNA/RNA for cell cultivation (TPP Techno Plastic Products AG, Trasadingen, Switzerland), were used as substrates. Tetrahydrofuran-HPLC grade (THF) and 2-ethoxyethanol p.a. (ETH), both from Sigma-Aldrich Ltd., (St. Louis, MO, USA) were used for surface microstructure production on the PS substrates [23]. Ar gas (purity 99.999\%, Messer Bad Soden am Taunus, Germany) and $\mathrm{CF}_{4}$ gas (purity 99.7\%, Air Liquide, Paris, France) were used.

The surfaces were modified with spin-coating. The solvent mixture was deposited onto the surface of the PS dishes with a specially constructed dosing device (Figure 1) rotating at $2200 \mathrm{rpm}$. The dosing of solvents was carried out by using a syringe placed $30 \mathrm{~mm}$ above the center of the rotating substrate. Each time, $0.4,1.0$, or $1.6 \mathrm{~mL}$ of a mixed solvent, divided into two, five, or eight consecutive doses of about $200 \mu \mathrm{L}$, was deposited in $5 \mathrm{~s}$ intervals on the surface of the PS dishes. After the last dose, the sample was left to rotate for another $120 \mathrm{~s}$. Unless otherwise stated, all the experiments were performed at a temperature of $295 \mathrm{~K}$ (substrate, solutions, and surrounding atmosphere) or a temperature of $303 \mathrm{~K}$ for solutions. Besides that, the air humidity was monitored and kept at $50 \% \pm$ $2 \%$, as described in our previous work [23]. 


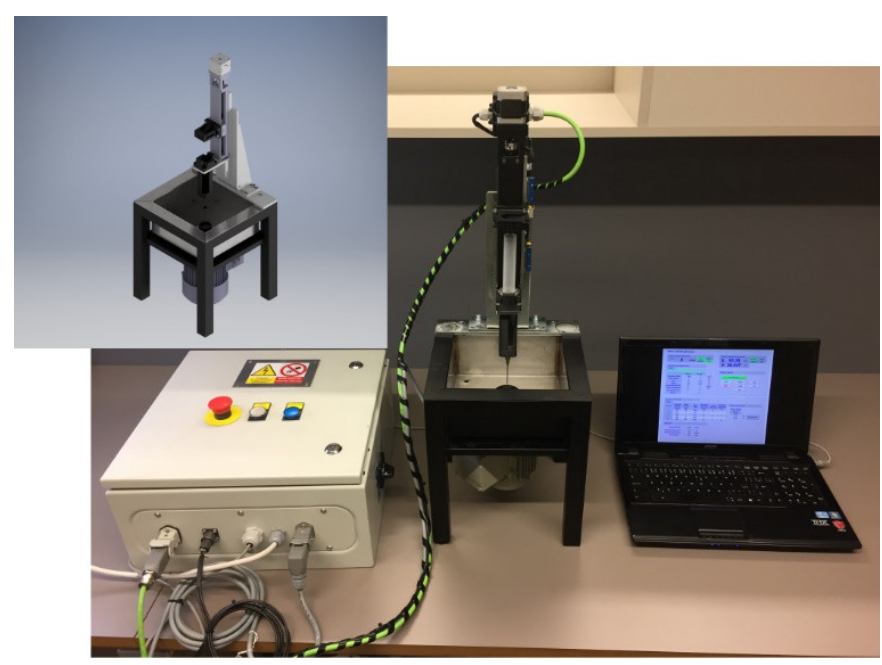

Figure 1. The dosing device constructed for the modification of the polymer surface topography (TSSC) by phase separation at rotation. The device consists of the sample carrier on the rotor, the dosing unit, and the control electronics.

A specially constructed device (Figure 1), a time-sequenced phase-separation chamber (TSSC, home made), is proposed for the generation of micro- and nanoporous polymer systems at rotation. The TSSC allows for the control of all of the process parameters of the previously described time-sequenced phase separations during rotation [23].

\subsection{Plasma Surface Modification}

Plasma treatment was performed in inductively coupled plasma in a discharge borosilicate glass tube with a full length of $80 \mathrm{~cm}$ and a $4 \mathrm{~cm}$ inner diameter. The gas pressure of $70 \mathrm{~Pa}$ in the glow-chamber was kept constant. Plasma was created by the radiofrequency (RF) generator Caesar 1312 (Advanced Energy, Warstein-Belecke, Germany) (Advanced Energy) coupled with a coil with six turns via a matching network. The matching network consisted of two vacuum-tunable capacitors. The generator operated at a standard frequency of $13.56 \mathrm{MHz}$ and an adjustable nominal power of up to $1200 \mathrm{~W}$. The matching system was optimized for $\mathrm{H}$ mode (forward power over $\sim 500 \mathrm{~W}$ and low reflected power) [46], but $\mathrm{E}$ mode (less than $500 \mathrm{~W}$ of forward power) was used for sample modification due to expected degradation. The RF power was varied, as is described further in the text. The plasma processing time was $2 \mathrm{~s}$ for Ar activation and $240 \mathrm{~s}$ for $\mathrm{CF}_{4}$ modification. The processing was identical for both the first and second plasma treatment steps.

\subsection{Scanning Electron Microscopy (SEM)}

Modified samples were analyzed with the JEOL JSM 6060 LV (JEOL USA, Inc., Peabody, MA, USA) and Phenom Pro (Phenom-World BV, Eindhoven, The Netherlands) scanning electron microscopes (SEM). Samples were observed at an acceleration voltage ranging from 1 to $5 \mathrm{kV}$ in the backscattered electron mode at a magnification ranging from $2000 \times$ to $50,000 \times$. Measurements were carried out on samples without prior metallization, using a special sample holder for the Phenom Pro, or with a carbon coating for the JEOL JSM 6060 LV in low vacuum mode.

\subsection{Atomic Force Microscopy (AFM)}

The surface topography was characterized by an atomic force microscope (AFM). The models Dimension ICON (Bruker, Santa Barbara, CA, USA) and NTEGRA-Prima (NT-MDT, Spectrum Instruments, Moscow, Russia) were used. Measurements were performed at a scan speed ranging from 0.3 to $0.7 \mathrm{~Hz}$, with a resolution of $512 \times 512$ pixels in tapping mode at room temperature under an air atmosphere. NSG01 (AppNano, Inc., Santa Clara, CA, USA) silicone probes were used. 


\subsection{Profilometry}

Changes in the surface roughness $\left(R_{\mathrm{a}}\right)$ were characterized by a contact profilometer (DektaXT, Bruker, Billerica, MA, USA). A diamond tip with a radius of curvature of 2 microns was used. The evaluation of the surface roughness was performed according to the ASME B46.1 standard [55]. The mean $R_{\mathrm{a}}$ values were determined from 10 individual measurements at various locations on the three samples.

\subsection{Distribution of Micropores}

The distribution of the pore areas was obtained by image analysis using ImageJ 1.5 software (Wayne Rasband, National Institutes of Health, Bethesda, MD, USA). The size of the individual micropores was determined from the thresholded SEM images.

\subsection{Contact Angle Measurement}

The sliding, advancing, receding, and static contact angles of water $(\theta)$ on the PS surface were characterized by the Drop Shape Analyzer-DSA 30 (Krüss GmbH, Hamburg, Germany). Measurements were done at room temperature $(298 \pm 1 \mathrm{~K})$ with $50 \%$ humidity. A drop of $3 \mu \mathrm{L}$ (for the static contact angle) or $10 \mu \mathrm{L}$ (for the sliding, advancing, and receding contact angle) was deposited onto the measured surface. Ultrapure water with a resistance of $18.2 \mathrm{M} \Omega \mathrm{cm}$ was used for the measurement. All measurements were repeated 10 times, and the mean values and standard deviations are reported.

\subsection{X-ray Photoelectron Spectroscopy (XPS)}

Samples were analyzed with the TFA XPS instrument (Physical Electronics, Lake Drive East Chanhassen, MN, USA). The base pressure in the chamber was about $6 \times 10^{-8} \mathrm{~Pa}$. The samples were excited with X-rays over a $400 \mu \mathrm{m}$ spot area, with a monochromatic $\mathrm{Al} \mathrm{K} \alpha$ with a radiation energy of $1486.6 \mathrm{eV}$ and a linewidth of $1.2 \mathrm{eV}$. The photoelectrons were detected with a hemispherical analyzer positioned at an angle of $45^{\circ}$ with respect to the perpendicular of the sample surface. Survey-scan spectra were acquired at a pass energy of $187.85 \mathrm{eV}$ and an energy step of $0.4 \mathrm{eV}$, while individual high-resolution spectra for $\mathrm{O} 1 \mathrm{~s}$ and $\mathrm{F} 1 \mathrm{~s}$ were taken at a pass energy of $23.5 \mathrm{eV}$ and an energy step of $0.1 \mathrm{eV}$, and at $11.75 \mathrm{eV}$ and $0.05 \mathrm{eV}$ for $\mathrm{C} 1$ s, respectively. An electron gun was used for surface neutralization. All spectra (not containing $\mathrm{F}$ ) were referenced to the main $\mathrm{C} 1$ peak of the carbon atoms, which was assigned a value of $284.8 \mathrm{eV}$. The spectra containing F were shifted to $291.8 \mathrm{eV}\left(\mathrm{CF}_{2}\right.$ binding of the carbon atom). The concentrations of the elements and the concentrations of the different chemical states of the carbon atoms in the $\mathrm{C} 1$ peaks were determined using the MultiPak v7.3.1 software from Physical Electronics. Carbon C1 peaks were fitted with symmetrical Gauss-Lorentz functions and the Shirley-type background subtraction was used.

\section{Results and Discussion}

For this study, PS samples with various surface structures were prepared according to the process described in our previous work [23]. It was found that the deposition of the heated solvent mixture $(303 \mathrm{~K})$ led to the formation of nanopores at the micropore edges (Figure 2 and Figure 4). These secondary pores are not attributed to higher hydrophobicities, as demonstrated by the water contact angle values in Figure $4 \mathrm{c}\left(115^{\circ} \pm 2^{\circ}\right)$ and Figure $4 \mathrm{e}\left(107^{\circ} \pm 2^{\circ}\right)$. To further increase the hydrophobicity, homogenous surface nanotextures have to be created, similar to natural materials [28], and $\mathrm{CF}_{x}$ functional groups have to be introduced onto the surface. 


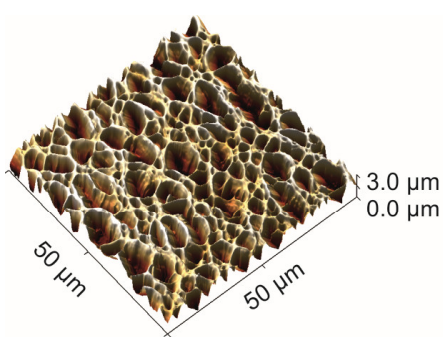

(a)

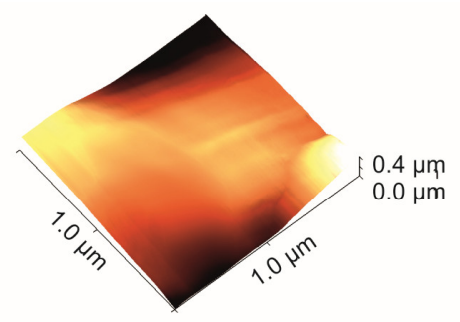

(b)

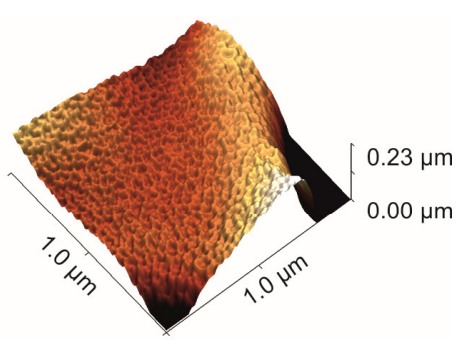

(c)

Figure 2. Surface micro- and nanotextures at the micropore border generated by inductively coupled Ar and $\mathrm{CF}_{4}$ plasma: (a) microporous polystyrene (PS) with a smooth border; (b) detail of the smooth border before plasma treatment; (c) detail of the smooth border after plasma treatment. All images represent atomic force microscope (AFM) micrographs. The smooth borders were prepared with five doses of 1.5 THF:8.5 ETH at $295 \mathrm{~K}$. The power of the plasma reactor was $300 \mathrm{~W}$.

Within this study, the plasma treatment process was optimized for PS microtextured surface modification [23], in order to create secondary surface corrugation (Figure 2 and Figure 4). Plasma treatment parameters, such as treatment time, plasma power, and gas flow, had to be optimized. Some of the parameters will be discussed in the context of primary pore generation with the time-sequenced phase separation technique.

As can be seen from the data in Figure 3, the most hydrophobic surface was reached at $300 \mathrm{~W}$ plasma power and a contact angle of $146^{\circ} \pm 2^{\circ}$. Lower plasma power $(250 \mathrm{~W})$ resulted in less intense surface modification and a final contact angle of $139^{\circ} \pm 1^{\circ}$. Higher plasma power $(350 \mathrm{~W})$, on the other hand, caused unwanted surface degradation and the contact angle reached $143^{\circ} \pm 1^{\circ}$.

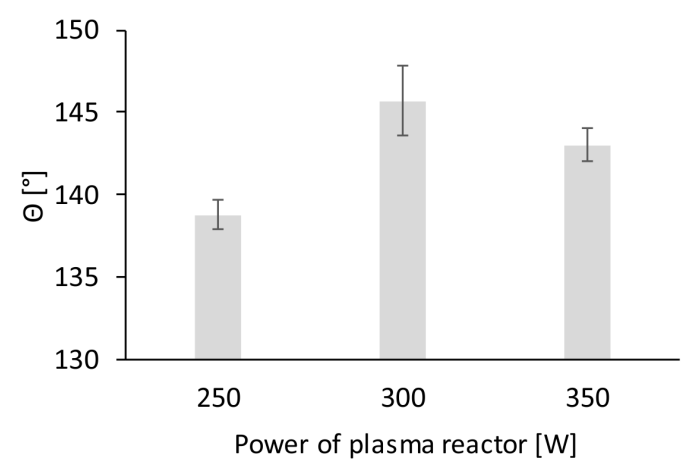

Figure 3. Water contact angle vs. plasma power on the PS surface with smooth pore borders with one cycle of plasma treatment. The smooth borders were prepared using five doses in 1.5 THF:8.5 ETH at $295 \mathrm{~K}$.

The experiments revealed that in order to achieve homogenous surface corrugation on the PS pore boundaries (Figure $4 \mathrm{~b}, \mathrm{~d}, \mathrm{f}$ ) and to stabilize the surface modifications, it is necessary to set the optimal plasma power $(300 \mathrm{~W})$ and to repeat the plasma treatment twice. The data from Figure 4 suggest that the specific nanotexture can be generated, regardless of the initial surface topography. With the smooth surface, the water contact rises by an angle of $32^{\circ}$ (Figure $4 a, b$ ), while at the microporous surface, it rises by $43^{\circ}$ (Figure $4 \mathrm{c}-\mathrm{f}$ ). This observation is related to the well-known effect of the combined microand nanotexture upon surface wetting [28]. These results could possibly indicate that the process of primary pore generation with phase separation does not affect the wetting characteristics of the plasma-treated surfaces. However, these appearances are deceptive, as the absolute values of the water contact sliding angles were $5^{\circ} \pm 1^{\circ}$ (Figure $4 \mathrm{~d}$ ) and $8^{\circ} \pm 1^{\circ}$ (Figure $4 \mathrm{f}$ ). The corresponding advancing and receding water contact angles were $158^{\circ} \pm 1^{\circ}$ and $156^{\circ} \pm 1^{\circ}$, respectively for Figure $4 \mathrm{~d}$ and $151^{\circ} \pm 1^{\circ}$ and $148^{\circ} \pm 1^{\circ}$, respectively, for Figure $4 \mathrm{f}$. 


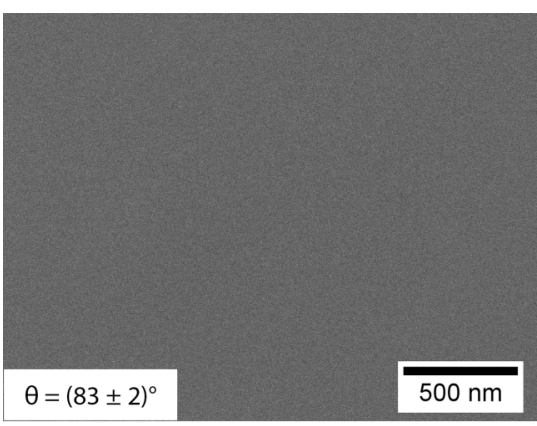

(a)

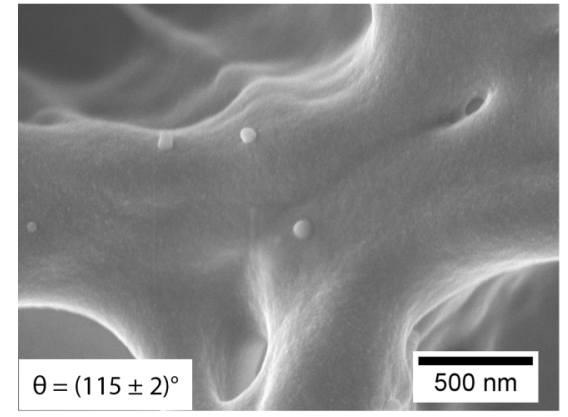

(c)

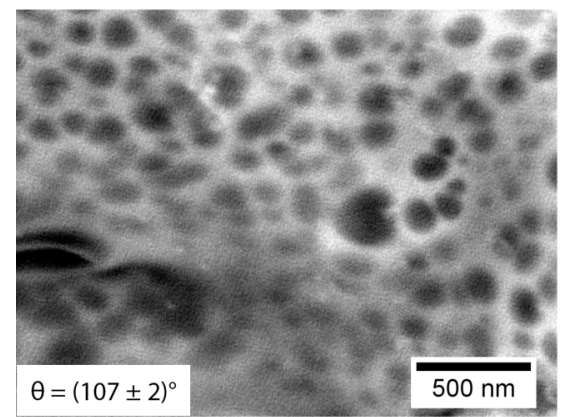

(e)

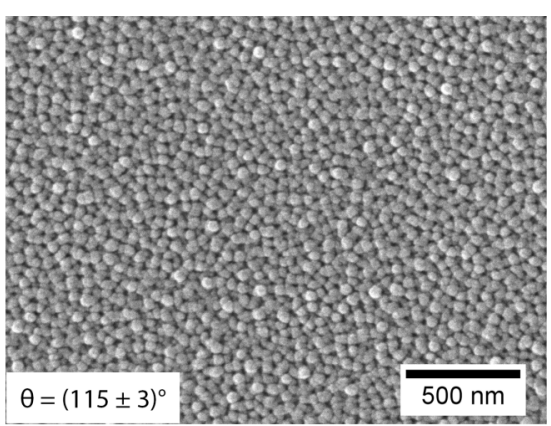

(b)

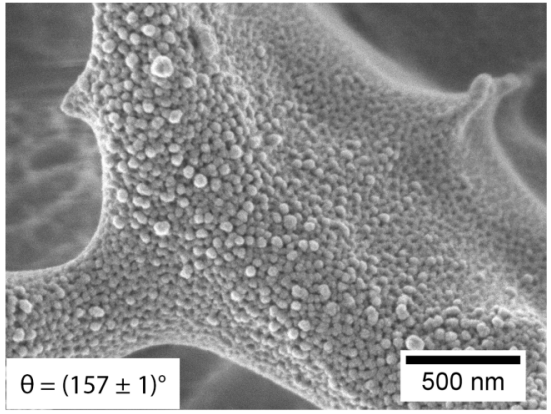

(d)

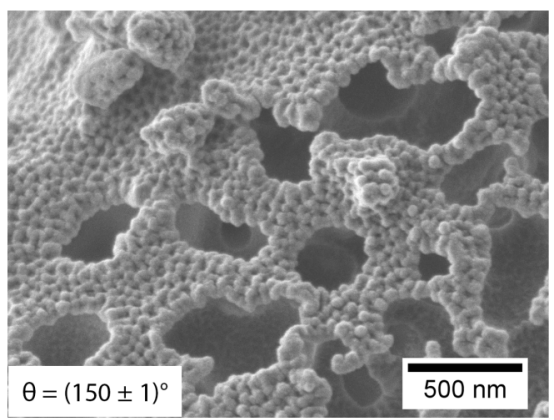

(f)

Figure 4. The effect of plasma etching on different types of PS substrate and the corresponding water contact angle: (a) flat PS; (b) $\mathrm{CF}_{4}$ plasma-treated flat PS; (c) porous PS with a smooth border; (d) $\mathrm{CF}_{4}$ plasma-treated porous PS with a smooth border; (e) porous PS with a porous border; $(\mathbf{f}) \mathrm{CF}_{4}$ plasma-treated porous PS with a porous border. The images represent SEM micrographs. The smooth borders were prepared using five doses of $1.5 \mathrm{THF}: 8.5 \mathrm{ETH}$ at $295 \mathrm{~K}$. The porous borders were prepared using five doses of $2.5 \mathrm{THF}: 7.5 \mathrm{ETH}$ at $303 \mathrm{~K}$. The power of the plasma reactor was $300 \mathrm{~W}$.

Two distinct surface morphologies, differing in pore border appearance were used for plasma treatment: (1) a smooth border (Figure 4c) including five doses of the solvent mixture (THF:ETH in a volume ratio of 1.5:8.5) deposited in five second intervals at $295 \mathrm{~K}$, and (2) a porous border (Figure 4e) including five doses of the solvent mixture (THF:ETH, in a volume ratio of 2.5:7.5) deposited in five second intervals at $303 \mathrm{~K}$.

The stability of the plasma treatment was observed by means of the water contact angle measurements. The data were recorded on the first, second, third, and fourth days after plasma treatment (Figure 5). As expected, the untreated samples remained stable during the whole time period. The plasma-treated samples stayed stable up to the second day, and then a slight decrease in contact angle value was observed. After 14 days, the water contact angle remained in the range of $140^{\circ}-152^{\circ}$, depending on the initial surface microstructure. 


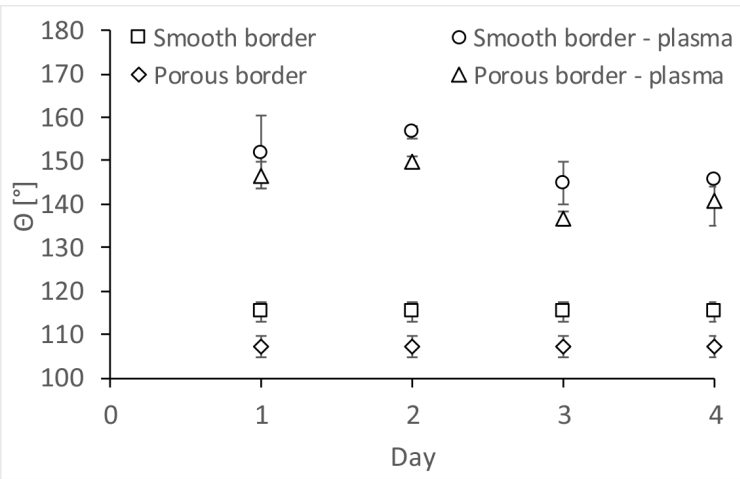

Figure 5. Water contact angle vs. time on the plasma-treated samples of PS substrates with smooth borders and porous borders and two cycles of plasma treatment. The smooth borders were prepared by five doses of $1.5 \mathrm{THF}: 8.5 \mathrm{ETH}$, at $295 \mathrm{~K}$. The porous borders were prepared with five doses of 2.5 THF:7.5 ETH at $303 \mathrm{~K}$. The power of the plasma reactor was $300 \mathrm{~W}$.

The initial experiments revealed that the two-fold plasma treatment resulted in the elimination of the bonded oxygen from the surface, and thus, the water contact angle rose (Table 1). This corresponded with the accelerated reorganization of the surface functional groups in the second cycle of the plasma treatment. Otherwise, this change would have occurred spontaneously in the following days after the first plasma treatment cycle [53]. This hypothesis is further supported by the increase in the water contact angle value in the second and third day after the one-cycle plasma treatment.

Table 1. Surface composition of the microporous PS with the smooth border and the corresponding water contact angles after the repeated plasma treatment. The smooth borders were prepared with five doses of 1.5 THF:8.5 ETH at $295 \mathrm{~K}$. The power of the plasma reactor was $300 \mathrm{~W}$.

\begin{tabular}{cccccc}
\hline $\begin{array}{c}\text { Porous PS (Smooth Border) (XPS } \\
\text { Characterization Immediately after } \\
\text { Processing) }\end{array}$ & \multicolumn{4}{c}{$\begin{array}{c}\text { XPS Elemental } \\
\text { Composition }( \pm \mathbf{0 . 5} \%)\end{array}$} & \multirow{\theta}{*}[{}^{\circ}]{} \\
\cline { 2 - 4 } & $\mathbf{C ~ ( \% )}$ & $\mathbf{F ~ ( \% )}$ & $\mathbf{O ~ ( \% )}$ & \\
\hline First plasma treatment & 38.4 & 56.7 & 5.0 & $142 \pm 3$ \\
Second plasma treatment & 43.0 & 56.3 & 0.7 & $157 \pm 1$ \\
\hline
\end{tabular}

The sample surface of the chemical composition and the type of chemical bonds did not change, even after 14 days, as can be seen from the comparison in Table 1 (second row) and Table 2 (fourth row). The data in Table 2 show that the highest bonded fluorine concentration was observed in microporous smooth-border samples and porous-border samples. $\mathrm{C}-\mathrm{CF}, \mathrm{C}-\mathrm{F}$, and $\mathrm{CF}_{2}$, and in some cases, $\mathrm{CF}_{3}$ dominated over the $\mathrm{C}-\mathrm{C}$ bonds, which, in turn, dominated the smooth plasma-treated PS surface.

Table 2. XPS characterization of plasma-untreated and treated PS substrates 14 days from processing. The smooth borders were prepared by five doses of 1.5 THF:8.5 ETH at $295 \mathrm{~K}$. Porous borders were prepared with five doses of $2.5 \mathrm{THF}: 7.5 \mathrm{ETH}$ at $303 \mathrm{~K}$. The power of the plasma reactor was $300 \mathrm{~W}$.

\begin{tabular}{|c|c|c|c|c|c|c|c|c|}
\hline \multirow{2}{*}{$\begin{array}{c}\text { Sample Type (XPS Characterization } \\
14 \text { Days after Processing) }\end{array}$} & \multicolumn{3}{|c|}{$\begin{array}{c}\text { XPS Elemental } \\
\text { Composition }( \pm 0.5 \%)\end{array}$} & \multicolumn{5}{|c|}{ Type of Chemical Bonds } \\
\hline & $\mathrm{C}(\%)$ & F (\%) & O (\%) & $\mathrm{C}-\mathrm{C}(\%)$ & $\mathrm{C}-\mathrm{CF}(\%)$ & C-F (\%) & $\mathrm{CF}_{2}(\%)$ & $\mathrm{CF}_{3}(\%)$ \\
\hline Flat PS & 96.6 & - & 2.6 & 100.0 & - & - & - & - \\
\hline Plasma-Flat PS & 44.8 & 54.6 & 0.6 & 23.7 & 12.1 & 14.1 & 37.2 & 13.0 \\
\hline Porous PS (smooth border) & 94.6 & - & 3.5 & 100.0 & - & - & - & - \\
\hline Plasma-Porous PS (smooth border) & 42.9 & 56.6 & 0.5 & 15.6 & 15.0 & 22.2 & 38.2 & 9.1 \\
\hline Porous PS (porous border) & 97.0 & - & 2.5 & 100.0 & - & - & - & - \\
\hline Plasma-Porous PS (porous border) & 41.7 & 58.3 & 1.0 & 14.2 & 11.6 & 24.3 & 37.7 & 12.3 \\
\hline
\end{tabular}

The discussed smooth-border and porous-border surfaces have distinct pore sizes and size distributions (Figures 6 and 7). Still, stemming from the inserts in Figure 6, the water contact angle 
before the plasma treatment was almost identical on all surfaces. Only after two cycles of plasma treatment could differences be observed. The highest value of the contact angle $\left(157^{\circ}\right)$ was achieved at the surface, with an intermediate pore size and roughness of $117 \mu \mathrm{m}$. The surfaces with the smallest and largest pores had water contact angles of $145^{\circ}$ and $146^{\circ}$, respectively. To achieve maximum hydrophobicity, it was necessary to adjust the pore size (Figure 6d) and depth (Figure 6e).

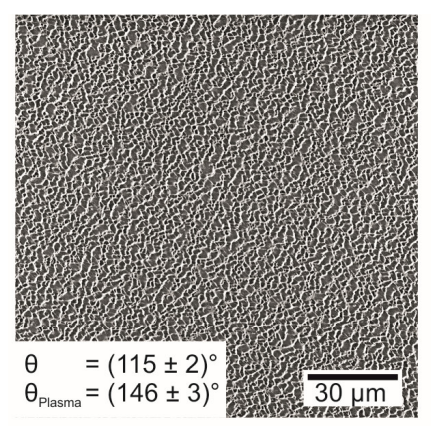

(a)

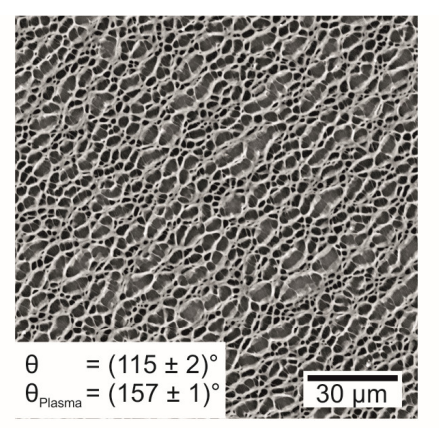

(b)

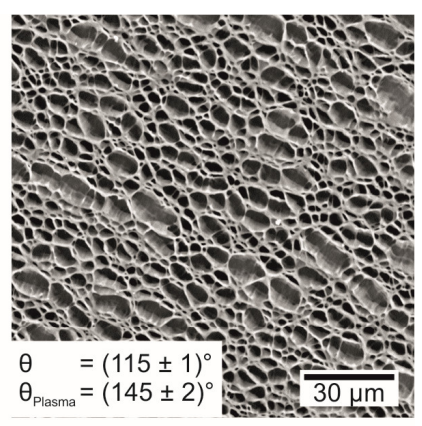

(c)

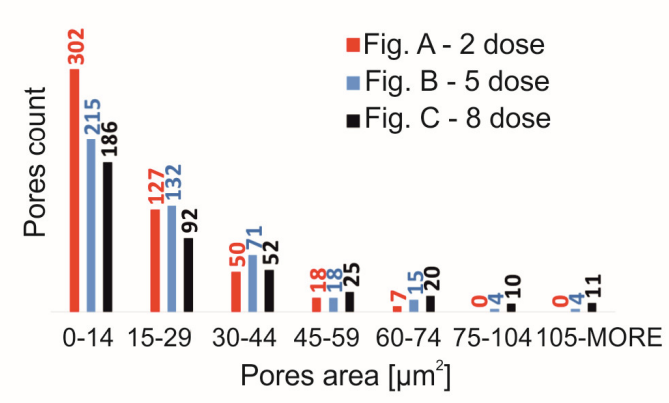

(d)

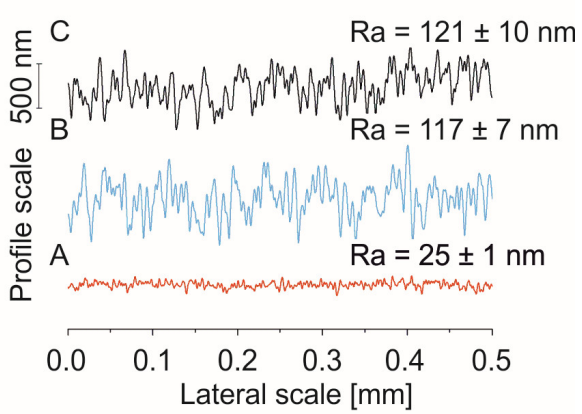

(e)

Figure 6. The effect of PS surface microtopography on the water contact angle values after plasma modification. The smooth borders of the microtextured surfaces were prepared from (a) two, (b) five, and (c) eight doses used in the time-sequenced phase separation process [23]. Pore size distribution (d), and surface profiles (e). SEM micrographs $(\mathbf{a}-\mathbf{c})$. The smooth borders were prepared with two, five, or eight doses of $1.5 \mathrm{THF}: 8.5 \mathrm{ETH}$ at $295 \mathrm{~K}$. The power of the plasma reactor was $300 \mathrm{~W}$.

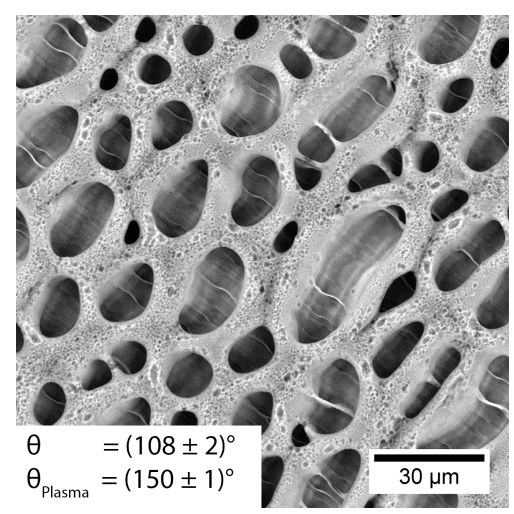

Figure 7. SEM micrograph of microtextured PS with a porous border. Water contact angles prior to and after plasma modification. Porous-borders were prepared by five doses of 2.5 THF:7.5 ETH at 303 $\mathrm{K}$. The power of plasma reactor was $300 \mathrm{~W}$.

Other situations occurred, with secondary nanopores presented on the micropore boundaries (Figure 7). Such kinds of surfaces have high contact angle values, although small amounts of large pores are present on the surface, and the roughness is relatively very high $\left(R_{\mathrm{a}}=634 \pm 57 \mu \mathrm{m}\right)$. 


\section{Conclusions}

The potential of the plasma hydrophobization of micro- and nanoporous PS substrates was studied. It was found that the single combination of phase-separation methods and $\mathrm{CF}_{4}$ plasma enabled the quick preparation of various types of hierarchically structured surfaces with superhydrophobic properties. It was also found that the hydrophobic behavior is dictated not only by the pore size and thickness but also by the interface separating the individual pores generated in the phase separation process. With the appropriate plasma power and repeated exposure to the plasma, highly hydrophobic surfaces with specific surface nanotextures can be prepared. Such induced changes, both topographic and chemical, are very stable, and the treated surfaces are not subject to aging within a time period of several weeks.

Author Contributions: Conceptualization, A.M. (Aleš Mráček) and A.M. (Antonín Minařík); Methodology, M.M. (Martin Minařík), A.M. (Antonín Minařík), O.G., E.W. and A.M. (Aleš Mráček); Validation, M.M. (Martin Minařík), L.M., A.M. (Antonín Minařík) and A.M. (Aleš Mráček); Formal Analysis, A.M. (Antonín Minařík), B.P., M.M. (Martin Minařík) and O.G.; Investigation, M.M. (Martin Minařík), A.M. (Antonín Minařík), P.S., E.W. and A.M. (Aleš Mráček); Resources, A.M. (Aleš Mráček) and A.M. (Antonín Minařík); Writing-Original Draft Preparation, A.M. (Aleš Mráček) and A.M. (Antonín Minařík); Writing-Review and Editing, A.M. (Aleš Mráček) A.M. (Antonín Minařík) and P.S.; Visualization, M.M. (Martin Minařík), E.W., O.G. and A.M.; supervision, A.M. (Aleš Mráček), M.M. (Miran Mozetič), A.M. (Antonín Minařík), I.J. and G.P.

Funding: The research was funded by the Ministry of Education, Youth and Sports of the Czech Republic-Program NPU I (LO1504) and the European Regional Development Fund (No. CZ.1.05/2.1.00/19.0409) as well as by TBU (Nos. IGA/FT/2017/011, IGA/FT/2018/011, and IGA/FT/2019/012) funded from the resources for specific university research.

Conflicts of Interest: The authors declare no conflict of interest.

\section{References}

1. Perez, J.M.; O'Loughin, T.; Simeone, F.J.; Weissleder, R.; Josephson, L. DNA-based magnetic nanoparticle assembly acts as a magnetic relaxation nanoswitch allowing screening of DNA-cleaving agents. J. Am. Chem. Soc. 2002, 124, 2856-2857. [CrossRef]

2. Imada, M.; Noda, S.; Chutinan, A.; Tokuda, T.; Murata, M.; Sasaki, G. Coherent two-dimensional lasing action in surface-emitting laser with triangular-lattice photonic crystal structure. Appl. Phys. Lett. 1999, 75, 316-318. [CrossRef]

3. Shastri, V.P.; Martin, I.; Langer, R. Macroporous polymer foams by hydrocarbon templating. Proc. Natl. Acad. Sci. USA 2000, 97, 1970-1975. [CrossRef] [PubMed]

4. Brown, P.S.; Talbot, E.L.; Wood, T.J.; Bain, C.D.; Badyal, J.P.S. Superhydrophobic Hierarchical Honeycomb Surfaces. Langmuir 2012, 28, 13712-13719. [CrossRef]

5. Wasser, L.; Vacche, D.S.; Karasu, F.; Müller, L.; Castellino, M.; Vitale, A.; Bongiovanni, R.; Leterrier, Y. Bio-inspired fluorine-free self-cleaning polymer coatings. Coatings 2018, 8, 436. [CrossRef]

6. Huang, Z.; Xu, W.; Wang, Y.; Wang, H.; Zhang, R.; Song, X.; Li, J. One-step preparation of durable super-hydrophobic MSR $/ \mathrm{SiO}_{2}$ coatings by suspension air spraying. Micromachines 2018, 9, 677. [CrossRef]

7. Jia, S.; Deng, S.; Luo, S.; Qing, Y.; Yan, N.; Wu, Y. Texturing commercial epoxy with hierarchical and porous structure for robust superhydrophobic coatings. Appl. Surf. Sci. 2019, 466, 84-91. [CrossRef]

8. Ishizaki, T.; Kumagai, S.; Tsunakawa, M.; Furukawa, T.; Nakamura, K. Ultrafast fabrication of superhydrophobic surfaces on engineering light metals by single-step immersion process. Mater. Lett. 2017, 193, 42-45. [CrossRef]

9. Boinovich, L.B.; Emelyanenko, A.M.; Modestov, A.D.; Domantovsky, A.G.; Emelyanenko, K.A. Not simply repel water: The diversified nature of corrosion protection by superhydrophobic coatings. Mendeleev Commun. 2017, 27, 254-256. [CrossRef]

10. Kadlečková, M.; Minařík, A.; Smolka, P.; Mráček, A.; Wrzecionko, E.; Novák, L.; Musilová, L.; Gajdošík, R. Preparation of textured surfaces on aluminum-alloy substrates. Materials 2018, 12, 109. [CrossRef]

11. Wang, S.; Liu, K.; Yao, X.; Jiang, L. Bioinspired surfaces with superwettability: New insight on theory, design, and applications. Chem. Rev. 2015, 115, 8230-8293. [CrossRef] [PubMed] 
12. Su, B.; Tian, Y.; Jiang, L. Bioinspired interfaces with superwettability: From materials to chemistry. J. Am. Chem. Soc. 2016, 138, 1727-1748. [CrossRef] [PubMed]

13. Widawski, G.; Rawiso, M.; François, B. Self-organized honeycomb morphology of star-polymer polystyrene film. Nature 1994, 369, 387-389. [CrossRef]

14. Beysens, D.; Knobler, C.M. Growth of breath figures. Phys. Rev. Lett. 1986, 57, 1433-1436. [CrossRef] [PubMed]

15. Ahmmed, K.M.T.; Mafi, R.; Kietzig, A.M. Colored poly (vinyl chloride) by femtosecond laser machining. Ind. Eng. Chem. Res. 2018, 57, 6161-6170. [CrossRef]

16. Ahmmed, K.M.T.; Patience, C.; Kietzig, A.M. Internal and external flow over laser-textured superhydrophobic polytetrafluoroethylene (PTFE). ACS Appl. Mater. Interfaces 2016, 8, 27411-27419. [CrossRef] [PubMed]

17. Aitken, J. Breath figures. Nature 1911, 86, 516-517. [CrossRef]

18. Rayleigh, L. Breath figures. Nature 1911, 86, 416-417. [CrossRef]

19. Rayleigh, L. Breath figures. Nature 1912, 90, 436-438. [CrossRef]

20. Bormashenko, E.; Balter, S.; Pogreb, R.; Bormashenko, Y.; Gendelman, O.; Aurbach, D. On the mechanism of patterning in rapidly evaporated polymer solutions: Is temperature-gradient-driven marangoni instability responsible for the large-scale patterning? J. Colloid Interface Sci. 2010, 343, 602-607. [CrossRef]

21. Stenzel-Rosenbaum, M.H.; Davis, T.P.; Fane, A.G.; Chen, V. Porous polymer films and honeycomb structures made by the selforganization of well-defined macromolecular structures created by living radical polymerization techniques. Angew. Chem. Int. Ed. 2001, 40, 3428-3432. [CrossRef]

22. Tian, Y.; Jiao, Q.; Ding, H.; Shi, Y.; Liu, B. The formation of honeycomb structure in polyphenylene oxide films. Polymer 2006, 47, 3866. [CrossRef]

23. Wrzecionko, E.; Minařík, A.; Smolka, P.; Minařík, M.; Humpolíček, P.; Rejmontová, P.; Mráček, A.; Minaříková, M.; Gřundělová, L. Variations of polymer porous surface structures via the time-sequenced dosing of mixed solvents. ACS Appl. Mater. Inter. 2017, 9, 6472-6481. [CrossRef] [PubMed]

24. DeRosa, M.; Hong, Y.; Faris, R.; Rao, H. Microtextured polystyrene surfaces for three- dimensional cell culture made by a simple solvent treatment method. J. Appl. Polym. Sci. 2014, 131, 40181-40190. [CrossRef]

25. Samuel, A.; Umapathy, S.; Ramakrishnan, S. Functionalized and postfunctionalizable porous polymeric films through evaporation-induced phase separation using mixed solvents. ACS Appl. Mater. Inter. 2011, 3, 3293-3299. [CrossRef]

26. Li, W.; Ryan, A.J.; Meier, I.K. Morphology development via reaction-induced phase separation in flexible polyurethane foam. Macromolecules 2002, 35, 5034-5042. [CrossRef]

27. Matsuzaka, K.; Jinnai, H.; Koga, T.; Hashimoto, T. Effect of oscillatory shear deformation on demixing processes of polymer blends. Macromolecules 1997, 30, 1146-1152. [CrossRef]

28. Bhushan, B.; Jung, Y.C. Natural and biomimetic artificial surfaces for superhydrophobicity, self-cleaning, low adhesion, and drag reduction. Prog. Mater. Sci. 2011, 56, 1-108. [CrossRef]

29. Ma, M.; Hill, R.M. Superhydrophobic surfaces. Curr. Opin. Colloid Interface Sci. 2006, 11, 193-202. [CrossRef]

30. Xiu, Y.; Zhu, L.; Hess, D.W.; Wong, C.P. Hierarchical silicon etched structures for controlled hydrophobicity/superhydrophobicity. Nano Lett. 2007, 7, 3388-3393. [CrossRef]

31. Wenzel, R.N. Resistance of solid surfaces to wetting by water. Ind. Eng. Chem. 1936, 28, 988-994. [CrossRef]

32. Baxter, S.; Cassie, A.B.D. The water repellency of fabrics and a new water repellency test. J. Text. Inst. Trans. 1945, 36, T67-T90. [CrossRef]

33. Cassie, A.B.D.; Baxter, S. Wettability of porous surfaces. Trans. Faraday Soc. 1944, 40, 546-551. [CrossRef]

34. Cassie, A.B.D.; Baxter, S. Large contact angles of plant and animal surfaces. Nature 1945, 155, $21-22$. [CrossRef]

35. Cassie, A.B.D. Contact angles. Discuss. Faraday Soc. 1948, 3, 11-16. [CrossRef]

36. Nosonovsky, M.; Bhushan, B. Roughness optimization for biomimetic superhydrophobic surfaces. Microsyst. Technol. 2005, 11, 535-549. [CrossRef]

37. Jung, Y.C.; Bhushan, B. Contact angle, adhesion, and friction properties of micro- and nanopatterned polymers for superhydrophobicity. Nanotechnology 2006, 17, 4970-4980. [CrossRef]

38. Milne, A.J.B.; Amirfazli, A. The Cassie equation: How it is mean to be used. Adv. Colloid Interface Sci. 2012, 170, 48-55. [CrossRef] [PubMed]

39. Bormashenko, E. Progress in understanding wetting transitions on rough surfaces. Adv. Colloid Interface Sci. 2015, 222, 92-103. [CrossRef] [PubMed] 
40. Mozetič, M.; Zalar, A.; Panjan, P.; Bele, M.; Pejovnik, S.; Grmek, R. A method of studying carbon particle distribution in paint films. Thin Solid Films 2000, 376, 5-8. [CrossRef]

41. Gunde, M.K.; Kunaver, M.; Mozetič, M.; Pelicon, P.; Simčič, J.; Budnar, M.; Bele, M. Microstructure analysis of metal-effect coatings. Surf. Coat. Int. B Coat. Trans. 2002, 85, 115-121. [CrossRef]

42. Kunaver, M.; Gunde, M.K.; Mozetič, M.; Hrovat, A. The degree of dispersion of pigments in powder coatings. Dyes Pigment. 2003, 57, 235-243. [CrossRef]

43. Mozetič, M. Controlled oxidation of organic compounds in oxygen plasma. Vacuum 2003, 71, 237-240. [CrossRef]

44. Kunaver, M.; Mozetič, M.; Gunde, M.K. Selective plasma etching of powder coatings. Thin Solid Films 2004, 459, 115-117. [CrossRef]

45. Drenik, A.; Vesel, A.; Mozetič, M. Controlled carbon deposit removal by oxygen radicals. J. Nucl. Mater. 2009, 386-388, 893-895. [CrossRef]

46. Mozetič, M. Surface modification of materials using an extremely non-equilibrium oxygen plasma. Mater. Tehnol. 2010, 44, 165-171.

47. Drenik, U.; Cvelbar, K.; Ostrikov, M.; Mozetič, M. Catalytic probes with nanostructured surface for gas/discharge diagnostics: A study of a probe signal behaviour. J. Phys. D Appl. Phys. 2008, 41, 115201. [CrossRef]

48. Ricard, A.; Gaillard, M.; Monna, V.; Vesel, A.; Mozetič, M. Excited species in $\mathrm{H}_{2}, \mathrm{~N}_{2}, \mathrm{O}_{2}$ microwave flowing discharges and post-discharges. Surf. Coat. Technol. 2001, 142-144, 333-336. [CrossRef]

49. Babič, D.; Poberaj, I.; Mozetič, M. Fiber optic catalytic probe for weakly ionized oxygen plasma characterization. Rev. Sci. Instrum. 2001, 72, 4110-4114. [CrossRef]

50. Vasiljević, J.; Gorjanc, M.; Tomšič, B.; Orel, B.; Jerman, I.; Mozetič, M.; Vesel, A.; Simončič, B. The surface modification of cellulose fibres to create super-hydrophobic, oleophobic and self-cleaning properties. Cellulose 2013, 20, 277-289. [CrossRef]

51. Ji, H.; Yang, J.; Wu, Z.; Hu, J.; Song, H.; Li, L.; Chen, G. A simple approach to fabricate sticky superhydrophobic polystyrene surfaces. J. Adhes. Sci. Technol. 2013, 27, 2296-2303. [CrossRef]

52. Vesel, A. Hydrophobization of polymer polystyrene in fluorine plasma. Mater. Tehnol. 2011, 45, 217-220.

53. Chvátalová, L.; Čermák, R.; Mráček, A.; Grulich, O.; Vesel, A.; Ponížil, P.; Minařík, A.; Cvelbar, U.; Beníček, L.; Sajdl, P. The effect of plasma treatment on structure and properties of poly (1-butene) surface. Eur. Polym. J. 2012, 48, 866-874. [CrossRef]

54. Grulich, O.; Kregar, Y.; Modic, M.; Vesel, A.; Cvelbar, U.; Mracek, A.; Ponizil, P. Treatment and stability of sodium hyaluronate films in low temperature inductively coupled ammonia plasma. Plasma Chem. Plasma Process. 2012, 32, 1075-1091. [CrossRef]

55. ASME B46.1-2009 Surface Texture (Surface Roughness, Waviness, and Lay); ASME: New York, NY, USA, 2009. 